\title{
Competitiveness Identification of Supply Chain Management Enterprises Based on DEMATEL-ANP Method
}

\author{
Huan Yang \\ School of Business and Administration, South China University of Technology, Guangzhou, China \\ Email: 461181073@qq.com
}

How to cite this paper: Yang, H. (2019) Competitiveness Identification of Supply Chain Management Enterprises Based on DEMATEL-ANP Method. Open Journal of Business and Management, 7, 93-105. https://doi.org/10.4236/ojbm.2019.71006

Received: January 24, 2018

Accepted: December 8, 2018

Published: December 11, 2018

Copyright $\odot 2019$ by author and Scientific Research Publishing Inc. This work is licensed under the Creative Commons Attribution International License (CC BY 4.0).

http://creativecommons.org/licenses/by/4.0/

\section{Open Access}

\begin{abstract}
This paper analyzes the main factors of the competitiveness of supply chain management enterprises, and identified them competitiveness by DEMATEL-ANP, creating an integrated evaluation model that combines decision making trial and evaluation laboratory (DEMATEL) and analytic network process (ANP) based on the correlation between indexes. DEMATEL can verify the dependent relationship and strength of indexes. ANP can calculate the weight of indexes. Finally, it takes Eternal Asia Supply Chain Management Enterprise as an example and calculates its competitiveness. The result of the evaluation not only confirms the interrelationship of each index, also can clarify the importance of each index, which will provide a scientific basis for the supply chain management enterprises to build their competitiveness.
\end{abstract}

\section{Keywords}

Supply Management Enterprise, DEMATEL-ANP Method, Competitiveness Identification

\section{Introduction}

The connection and interaction brought by the Internet has led to the restructuring of supply chain structure. The relationship between suppliers, manufacturers, consumers and third party members in the supply chain are changing dramatically: on the supply side, with the increasing degree of global integration, different geographical location, production capacity and management level make supply chain management becomes more difficult; on the production side, more requirements are putting forward for the efficiency and flexibility of supply 
chain management, due to the manufacturing enterprises continuously introduce new products; on the sales side, manufacturing enterprises control the channel through interacting closely with consumers by Internet, the value of the intermediary is reduced. Because of the above factors, supply chain management enterprises, such as Eternal Asia Supply Chain Management Company, Prolto Supply Chain Management Company and so on, which are falling into the fierce market competition.

At the same time, China's manufacturing industry is in the critical period of transformation and upgrading, and the rise of collaborative manufacturing will transform the working mode from "serial" to "parallel". Manufacturing industry need the supply chain management enterprises to embed the industrial chain, integrate the supply chain business into the production process, connect the supplier network effectively, and so on. Based on this situation, the state Council issued a long-term plan (2014-2020) for the development of the logistics industry, encouraging the supply chain integration for manufacturing industry, forming a group of supply chain management enterprises which can provide global sourcing and global distribution service, building the third-party supply chain management platform, enhancing the level of supply chain management of manufacturing industry.

The research on supply chain management enterprises has attracted a lot of attention, Song Hua [1] pointed out that the supply chain management companies providing a comprehensive supply chain management service for enterprises in the virtual industrial cluster, and completing the effective coordination of all participants in the industrial. Gao Zhijun [2], based on integration and interactive perspective, studied the coordination of Supply Chain Management Company and customers as well as suppliers. Wang Zixian [3] studied the operation mode of supply chain management enterprises and the development of supply chain management industry. The research on supply chain management enterprises mainly focuses on the concept connotation, function, operation mode and so on. The competitiveness of the supply chain management enterprises has an important influence on the strategy and the promotion of service ability. Therefore, it is necessary to establish a reasonable evaluation system and identify the competitiveness of the supply chain management enterprises.

As an integrator in modern service industry, the basic operating mode of Supply chain management enterprises is: to undertake the inventory management, distribution and logistics transportation, import and export, financing, tax and other outsourcing services of the process on production, through integrating resources and outsourcing to achieve service [1]. The supply chain is not directly involving in production, but through integrating resources and coordinating the transaction cost of the entire supply chain to provide supply chain management service.

In the management practice of China, just as Figure 1 shows, there are three typical supply chain management enterprises: the first is project cooperation, 


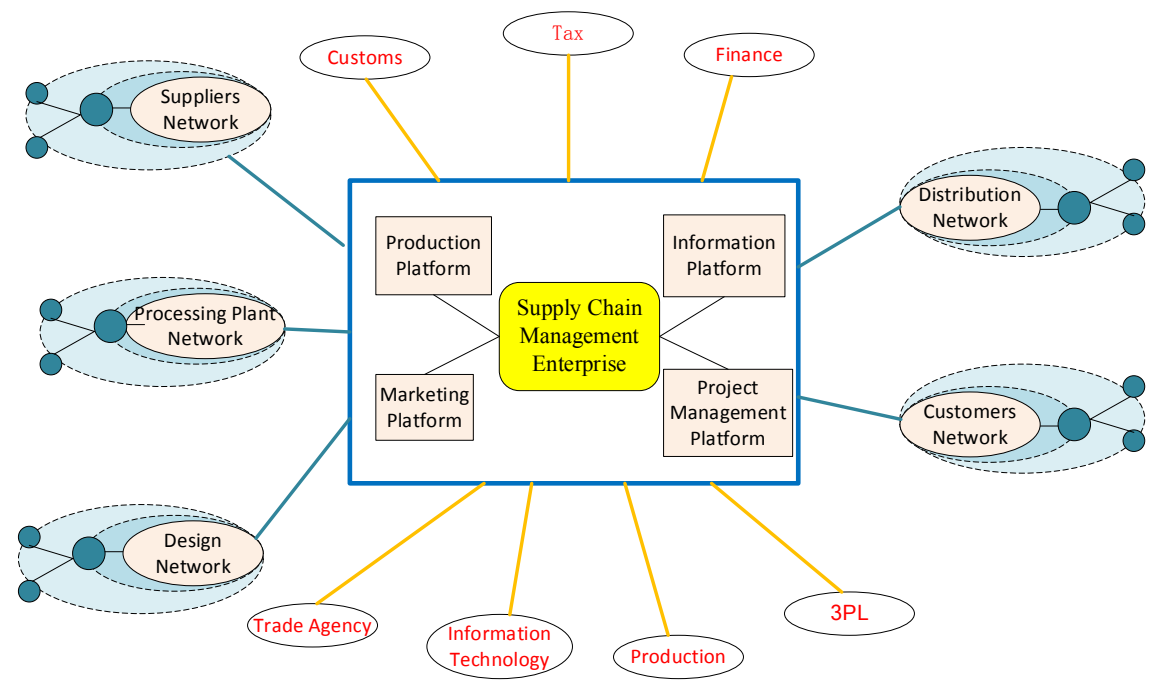

Figure 1. General situation of supply chain management enterprises.

which provide specialized process outsourcing such as BPO services in a project, the traditional third-party logistics is an example; the second is the business platform, which provides the integrated solution or scheme to the whole process; the third is the supply chain management enterprise that embedded in the industrial chain. This kind of supply chain management enterprises are embedded in the industrial chain network of manufacturing enterprises, on the one hand, it is convenient to integrate the horizontal common demand in the industrial chain and form the overall scale advantage; on the other hand, to promote the vertical integration of the industrial chain, through the control of logistics, capital flow, information flow, business flow to promote the vertical cooperation of the industrial chain, and play an integral role of the industrial chain.

\section{Impact Factors of the Competitiveness of Supply Chain Management Enterprises}

When receiving the order, the supply management enterprises need to disassemble the order according to customer needs, coordinate supply chain between resources and customers. So we analysis the impact factors of the competitiveness of supply chain management enterprises with resources and customers as well as supply chain coordination.

\subsection{Resources}

Supply chain management enterprises meet customer needs through their own resources and supplier resources [4], because supplier's specific knowledge and ability to the single link is conducive to the completion of service. So we divide resources into internal resources and suppliers' resources [5].

In the aspect of inner resources, some customer enterprises because lack of logistics infrastructure, supply chain management experiences and distributors resources can not operate normally [6]. Supply chain management enterprises 
with their own resources-advantage, human resources, technical advantage and service networks to help customer enterprises. So we use three indicators (human resources, technical patents and service networks) to measure inner resources.

In the aspect of suppliers' resources, suppliers are important social resources for enterprises. Selecting the supplier's ability is the guarantee of quality service [7]. Through pay attention to the supplier, we can establish the strategic partnership between the enterprises and the suppliers, strengthen the trust and commitment of each other and promote the good cooperation in the industrial chain. Communicate with suppliers can help suppliers quickly master the information of customers' products and production schedules in time. So we use three indicators (suppliers selecting, pay attention to suppliers and communicate with suppliers) to measure suppliers management.

\subsection{Customers}

Enterprises' customers take participate in production as a partner, and co-create value with supply chain management enterprises [8]. Understanding customers' demand is the necessary factor for the supply chain management enterprises to win in fierce market competition. Supply chain management enterprises, to a certain extent, need to contact the customer's production plan or other business secrets [9], so need to form close partnership with customers. Customers demand management and partnership with customers are two key factors to manage customers [10].

In the aspect of customers demand management, the service level is the direct embodiment of the enterprise's effective management of the customer's demand. The information communication can promote the supply chain to reduce the bullwhip effect. It is also important to improve the service according to the change of customer's dynamic demand [11]. So we use three indicators (service level, information communication and service improvement) to measure customers demand management.

In the aspect of customers' relationship management, customers' satisfaction and customers loyalty affect the long-term relationship between enterprises and customers, so they are the key to customer relationship management. Enterprises and customers form a stable strategic partnership, can enhance the communication of information to maintain consistency [12], so that enterprises and customer integration level has been promoted. So we use three indicators (customers' satisfaction, customers loyalty and strategic partnership) to measure customers relationship management.

\subsection{Supply Chain Coordination}

The most remarkable feature of supply chain management service is not stored, and needs to coordinate the supply chain. Supply chain flexibility and supply chain response ability are key factors in supply chain coordination [13]. 
In the aspect of supply chain response ability, delivery cycle, delivery in time reflect the response efficiency of the supply chain management enterprises [14]. The timely response to problems reflects the dynamic response ability. So we use three indicators (delivery cycle, delivery in time and response to problems) to measure supply chain response ability.

In the aspect of supply chain flexibility, flexible delivery and combination flexibility are the important factors to adapt dynamic environment of enterprises [15]. The ability of strain is the ability to adjust itself according to the environment. So we use three indicators (flexible delivery, combination flexibility and ability of strain) to measure supply chain flexibility.

We use Figure 2 to show the indicators of evaluation model.

\section{The Evaluation Model Based on DEMATEL-ANP Method}

When evaluating the competitiveness, it is necessary to consider the high-impact relationships between every factor. The DEMATEL (Decision Making Trial and

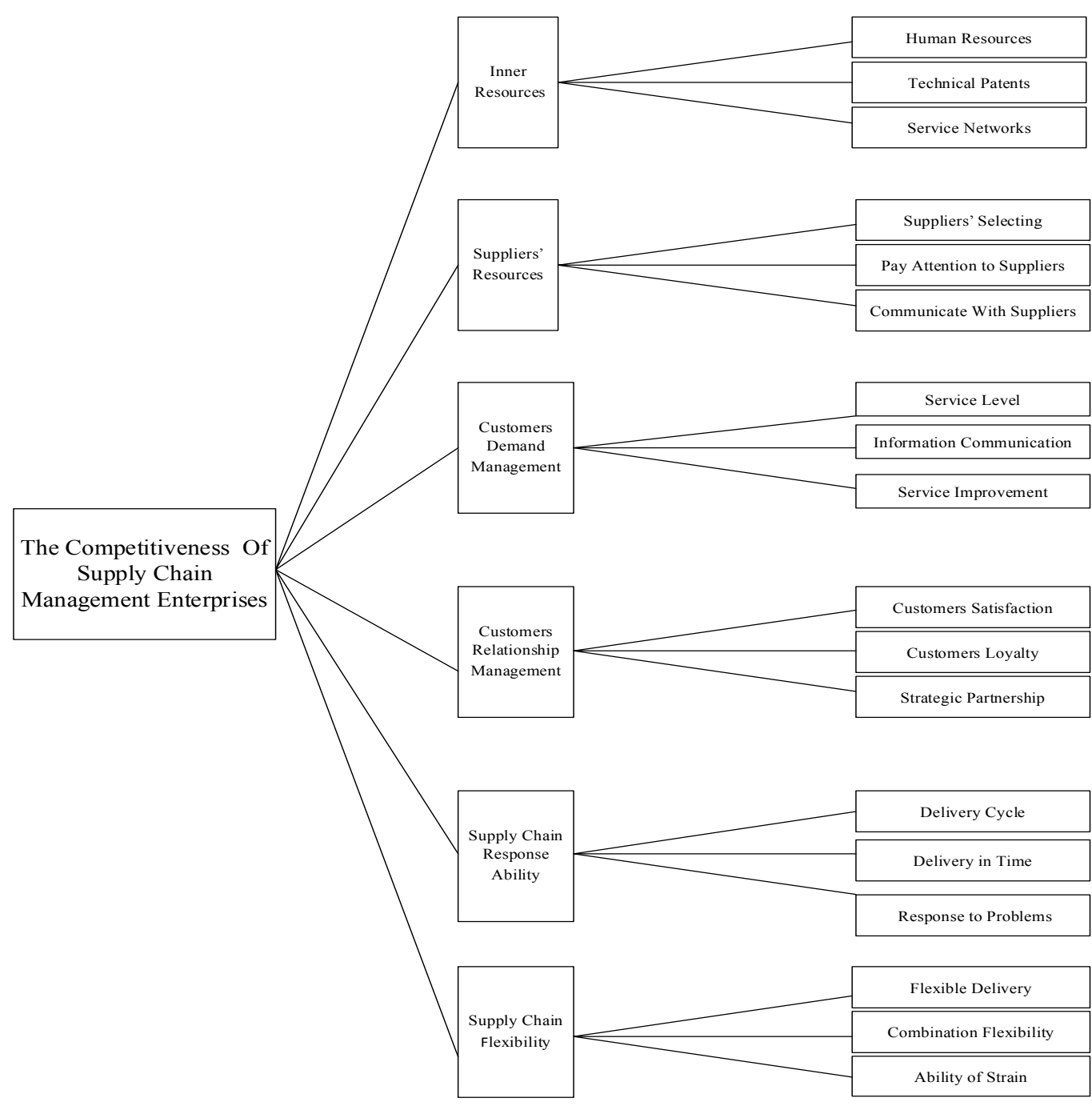

Figure 2. The indicators of evaluation model. 
Evaluation Laboratory) method was developed in the Battelle Geneva Institute to analyze complex problems using interactive model techniques and to evaluate quantitative and factor-linked aspects of social problems. DEMATEL was used for the fragmented and antagonistic phenomena of world societies and to develop integrated solutions. This method tries to achieve a weighted hierarchical structural model by analyzing the quantitative data on the strength of pair relations on each two factors. The ANP methodology can support complex, networked decision making with various intangible criteria. It improves the visibility of decision making processes and generates the priorities of the decision alternatives. Figure 3 shows the processes of DEMATEL-ANP method.

The DEMATEL method is important and useful for determining the structural model of a problematique in which it is possible to prioritize multiple strategies to improve its structure. A complex problematique is composed of several factors. The steps of DEMATEL are as follows:

1) Extracting the factors and investigating binary relations: We extract all the problematique factors and identify the binary relations and strength for finding the causality.

2) Deriving the direct-relation matrix: If the problematique is composed of $n$ factors, the $n \times n$ matrix $X$ is obtained by comparing the binary relations and strength. $X$ is the direct matrix. The $(i, j)$ element $x_{i j}$ of matrix $X$ denotes the amount of direct influence from factor $i$ to factor $j$. The amount of $x_{i i}$ is zero.

3) Normalizing the direct-relation matrix $X$ : The matrix $X$ is normalized as $Y=\lambda \cdot X$.

By using $\lambda=1 / \max _{1 \leq i \leq n}\left(\sum_{j=1}^{n} x_{i j}\right)$, we can derive the normalized matrix $Y$.

4) Deriving the direct/indirect matrix $T$ : Since $\lim _{\theta \rightarrow \infty} Y^{\theta}=[0]$, then we determine:

$$
T=Y+Y^{2}+\ldots=Y(I-Y)^{-1} .
$$

Matrix $T$ is the direct/indirect matrix.

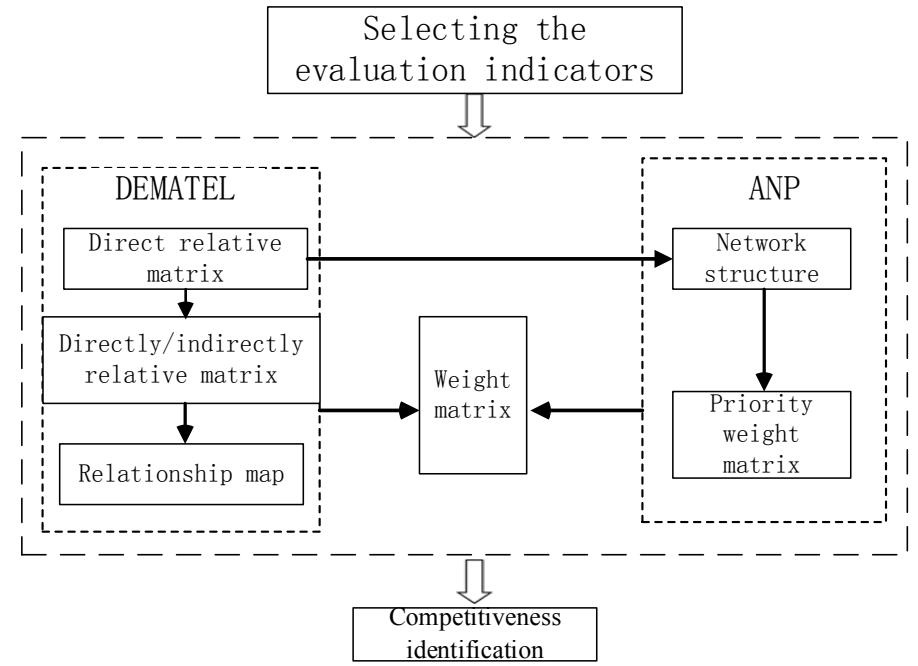

Figure 3. The processes of DEMATEL-ANP method. 
The $(i, j)$ element $t_{i j}$ of matrix $T$ denotes the direct and indirect influence from factor $i$ to factor $j$.

5) Obtaining a causal diagram: Suppose Di represents the row sum of $i$ th row of matrix $T$. It shows the sum of influence dispatching from factor $i$ to the other factors both directly and indirectly. Suppose $R_{i}$ denotes the column sum of $i$ thcolumn of matrix $T$, then $R_{i}$ represents the sum of influence that factor $i$ receives from the other factors. The sum of rows and columns $\left(D_{i}+R_{i}\right)$ denotes the index representing the strength of influence, both dispatching and receiving. This shows the degree to which factor $i$ plays a central role in the problematique. When $\left(D_{i}-R_{i}\right)$ is positive, it shows that factor $i$ is dispatching the influence to the other factors. If $D_{i}-R_{i}$ is negative, it means that the factor $i$ is receiving the influence from the other factors.

The ANP approach consists of two stages: the construction of the network and the calculation of the priorities of the elements. All of the interactions between the elements should be considered when building the structure of the problem. These interactions are evaluated using pairwise comparisons. A supermatrix is raised to limiting powers to determine the overall priorities, thus obtaining the cumulative influence of every element on each other factors.

\section{An Example of Competitiveness Identification of Supply Chain Management Enterprise}

Shenzhen Eternal Asia supply chain management company was founded in 1997, which provides comprehensive integration of supply chain management services to supply chain members. There are more than 30,000 employees, networks of them are over 380 cities in China and more than 10 countries and regions in the world. At present, Eternal Asia supply chain management company is the leading enterprise in the supply chain management industry.

\subsection{Determine the Relationship between Indicators-The Application of DEMATEL Method}

1) We get a direct relational matrix $A$ through the evaluation of the expert group.

$$
A=\left|\begin{array}{llllll}
0 & 1 & 4 & 2 & 3 & 2 \\
1 & 0 & 4 & 1 & 2 & 3 \\
0 & 0 & 0 & 4 & 2 & 2 \\
0 & 0 & 3 & 0 & 4 & 2 \\
0 & 1 & 4 & 2 & 0 & 3 \\
0 & 1 & 3 & 2 & 4 & 0
\end{array}\right|
$$

2) Through the formulas (1)-(3) to get the comprehensive impact matrix.

$$
k=\min \left(\frac{1}{\max \sum_{i=1}^{n} a_{i j}}, \frac{1}{\max \sum_{j=1}^{n} a_{i j}}\right)
$$




$$
\begin{gathered}
T=X(I-) X^{-1} \\
T=\left[\begin{array}{lllllll}
0.005 & 0.088 & 0.406 & 0.273 & 0.339 & 0.258 \\
0.057 & 0.034 & 0.388 & 0.213 & 0.279 & 0.291 \\
0.001 & 0025 & 0.145 & 0.305 & 0.244 & 0.206 \\
0.002 & 0.031 & 0.307 & 0.132 & 0.338 & 0.221 \\
0.004 & 0.079 & 0.364 & 0.245 & 0.165 & 0.275 \\
0.005 & 0.082 & 0.326 & 0.243 & 0.352 & 0.136
\end{array}\right]
\end{gathered}
$$

3) Adjust the comprehensive matrix. According to the expert opinion and repeated tests, the threshold value is: threshold $=0.007$. If the value of comprehensive impact matrix is less than 0.007 , it means that there is a lack of obvious correlation between the indicators, which is ignored. Adding each row and line, $D$ indicates the degree of influence, and $\mathrm{R}$ indicates the degree of influenced (Table $1)$.

4) Construct the cause and effect diagram according $D+R, D-R$. The relationship between indicators can be clearly identified from Figure 4 .

\subsection{Determine the Weight of Indicators-The Application of ANP Method}

1) Construct the network structure. According to the actual situation of the supply chain management enterprises and the relationship between indicators, the structure of the secondary indicators network is shown like Figure 5.

2) Construct the ANP judgment matrix. This paper deals with 18 secondary indicators, relationships of indicators are complex, so we used SuperDecision software to help study (Table $2 \&$ Table 3 ).

3) Determine the indicators weight. When all the data is entered, the SuperDecision software will automatically produce the indicators weight, collecting the experts' evaluation of the company can identify its competitiveness (Table 4).

\section{Conclusions}

The competitive advantages of Eternal Asia are internal resources, supplier

Table 1. The degree of influence of indicators.

\begin{tabular}{cccccccccc}
\hline & $\mathrm{U}_{1}$ & $\mathrm{U}_{2}$ & $\mathrm{U}_{3}$ & $\mathrm{U}_{4}$ & $\mathrm{U}_{5}$ & $\mathrm{U}_{6}$ & $D$ & $D+R$ & $D-R$ \\
\hline $\mathrm{U}_{1}$ & 0 & 0.088 & 0.406 & 0.273 & 0.339 & 0.258 & 1.364 & 1.364 & 1.364 \\
$\mathrm{U}_{2}$ & 0 & 0 & 0.388 & 0.213 & 0.279 & 0.291 & 1.171 & 1.420 & 0.922 \\
$\mathrm{U}_{3}$ & 0 & 0 & 0.145 & 0.305 & 0.244 & 0.206 & 0.900 & 2.836 & -1.036 \\
$\mathrm{U}_{4}$ & 0 & 0 & 0.307 & 0.132 & 0.338 & 0.221 & 0.998 & 2.409 & -0.413 \\
$\mathrm{U}_{5}$ & 0 & 0.079 & 0.364 & 0.245 & 0.165 & 0.275 & 1.128 & 2.845 & -0.589 \\
$\mathrm{U}_{6}$ & 0 & 0.082 & 0.326 & 0.243 & 0.352 & 0.136 & 1.139 & 2.526 & -0.248 \\
$\mathrm{R}$ & 0 & 0.249 & 1.936 & 1.411 & 1.717 & 1.387 & - & - & - \\
\hline
\end{tabular}




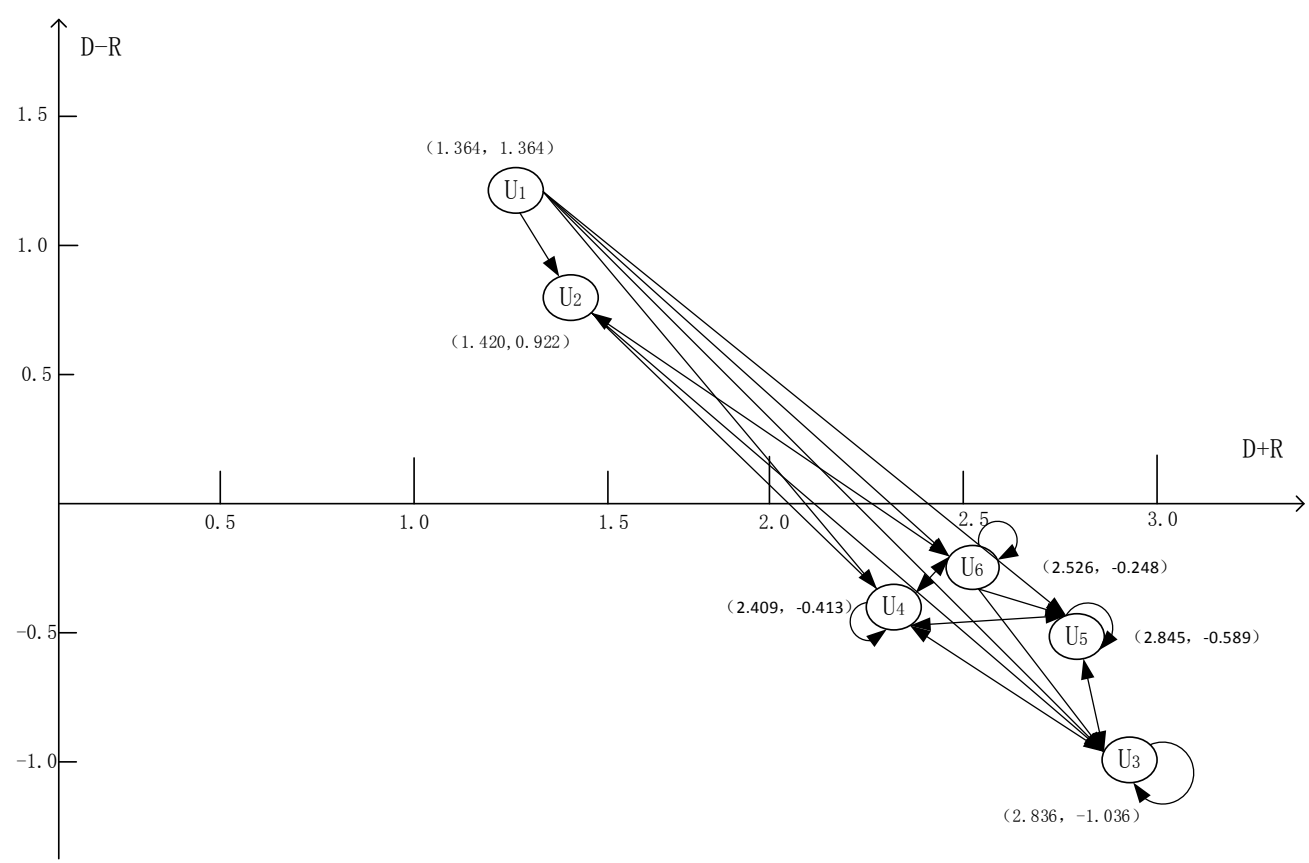

Figure 4. The relationship map.

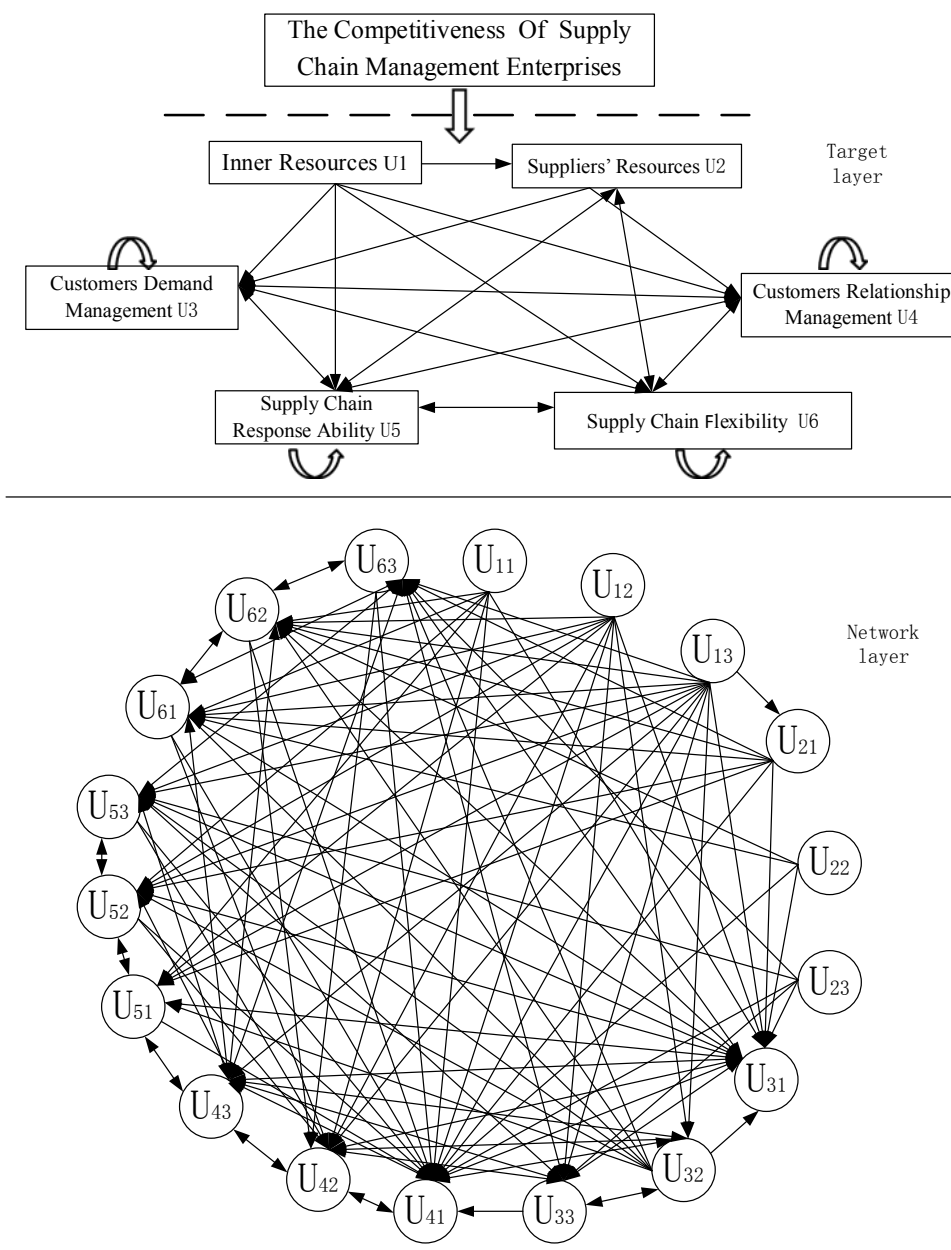

Figure 5. The network structure of indicators. 
Table 2. The judgment matrix under $\mathrm{U}_{2}$ rule.

\begin{tabular}{cccccc}
\hline & $\mathrm{U}_{1}$ & $\mathrm{U}_{3}$ & $\mathrm{U}_{4}$ & $\mathrm{U}_{5}$ & $\mathrm{U}_{6}$ \\
\hline $\mathrm{U}_{1}$ & 1 & 1 & 2 & 3 & 2 \\
$\mathrm{U}_{3}$ & 1 & 1 & 3 & 2 & 2 \\
$\mathrm{U}_{4}$ & $1 / 2$ & $1 / 3$ & 1 & $1 / 2$ & 1 \\
$\mathrm{U}_{5}$ & $1 / 3$ & $1 / 2$ & 2 & 1 & 2 \\
$\mathrm{U}_{6}$ & $1 / 2$ & $1 / 2$ & 1 & $1 / 2$ & 1 \\
\hline
\end{tabular}

Table 3. The judgment matrix of $U_{2}$ under $U_{21}$ rule.

\begin{tabular}{ccccc}
\hline & $\mathrm{U}_{31}$ & $\mathrm{U}_{32}$ & $\mathrm{U}_{33}$ & Weight \\
\hline $\mathrm{U}_{31}$ & 1 & 2 & 3 & 0.540 \\
$\mathrm{U}_{32}$ & $1 / 2$ & 1 & 2 & 0.292 \\
$\mathrm{U}_{33}$ & $1 / 3$ & $1 / 2$ & 1 & 0.168 \\
C.R. & & $\mathbf{0 . 0 1 5 9}$ (C.R. < 0.1) \\
\hline
\end{tabular}

Table 4. The competitiveness identification of EA company.

\begin{tabular}{|c|c|c|c|c|}
\hline $\begin{array}{l}\text { The First Level } \\
\text { Indicators }\end{array}$ & The Second Level Indicators & $\begin{array}{l}\text { Local Weight of } \\
\text { Indicators }\end{array}$ & $\begin{array}{l}\text { Total Weight of } \\
\text { Indicators }\end{array}$ & $\begin{array}{l}\text { The Evaluation } \\
\text { of EA Company }\end{array}$ \\
\hline \multirow{3}{*}{$\begin{array}{c}\text { Inner } \\
\text { Resources }\left(\mathrm{U}_{1}\right) \\
(0.216)\end{array}$} & Service Networks $\left(\mathrm{U}_{11}\right)$ & 0.752 & 0.162 & 0.154 \\
\hline & Technical Patents $\left(\mathrm{U}_{12}\right)$ & 0.125 & 0.027 & 0.022 \\
\hline & Human Resources $\left(\mathrm{U}_{13}\right)$ & 0.123 & 0.027 & 0.023 \\
\hline \multirow{3}{*}{$\begin{array}{c}\text { Suppliers' } \\
\text { Resources }\left(\mathrm{U}_{2}\right) \\
(0.067)\end{array}$} & Suppliers' Selecting $\left(\mathrm{U}_{21}\right)$ & 0.448 & 0.030 & 0.026 \\
\hline & Pay Attention to Suppliers $\left(\mathrm{U}_{22}\right)$ & 0.297 & 0.020 & 0.015 \\
\hline & $\begin{array}{l}\text { Communicate With Suppliers } \\
\left(\mathrm{U}_{23}\right)\end{array}$ & 0.255 & 0.017 & 0.013 \\
\hline \multirow{3}{*}{$\begin{array}{l}\text { Customers } \\
\text { Demand } \\
\text { Management } \\
\left(\mathrm{U}_{3}\right)(0.226)\end{array}$} & Service Level $\left(\mathrm{U}_{31}\right)$ & 0.540 & 0.122 & 0.112 \\
\hline & $\begin{array}{l}\text { Information Communication } \\
\left(\mathrm{U}_{32}\right)\end{array}$ & 0.292 & 0.066 & 0.059 \\
\hline & Service Improvement $\left(U_{33}\right)$ & 0.168 & 0.038 & 0.032 \\
\hline \multirow{3}{*}{$\begin{array}{l}\text { Customers } \\
\text { Relationship } \\
\text { Management } \\
\left(\mathrm{U}_{4}\right)(0.195)\end{array}$} & Customers Satisfaction $\left(\mathrm{U}_{41}\right)$ & 0.424 & 0.083 & 0.076 \\
\hline & Customers Loyalty $\left(\mathrm{U}_{42}\right)$ & 0.139 & 0.027 & 0.021 \\
\hline & Strategic Partnership $\left(\mathrm{U}_{43}\right)$ & 0.437 & 0.085 & 0.081 \\
\hline Supply Chain & Delivery Cycle $\left(\mathrm{U}_{51}\right)$ & 0.263 & 0.046 & 0.040 \\
\hline \multirow{2}{*}{$\begin{array}{l}\text { Response Ability } \\
\quad\left(\mathrm{U}_{5}\right)(0.175)\end{array}$} & Delivery in Time $\left(\mathrm{U}_{52}\right)$ & 0.547 & 0.096 & 0.091 \\
\hline & Response to Problems $\left(\mathrm{U}_{53}\right)$ & 0.190 & 0.033 & 0.030 \\
\hline \multirow{3}{*}{$\begin{array}{l}\text { Supply Chain } \\
\text { Flexibilit }\left(\mathrm{U}_{6}\right) \\
\quad(0.122)\end{array}$} & Flexible Delivery $\left(\mathrm{U}_{61}\right)$ & 0.298 & 0.036 & 0.029 \\
\hline & Combination Flexibility $\left(\mathrm{U}_{62}\right)$ & 0.361 & 0.044 & 0.039 \\
\hline & Ability of Strain $\left(\mathrm{U}_{63}\right)$ & 0.341 & 0.041 & 0.038 \\
\hline & Total & & 1 & 0.903 \\
\hline
\end{tabular}

management, customer relationship management, supply chain response, supply chain flexibility, but it is not good at customer demand management. The per- 
formance of competitive advantage of Eternal Asia is as follows:

1) In terms of internal resource integration capabilities, EA has an international logistics distribution network, bonded logistics network and operation network throughout China and the Asia-Pacific regions, and has ten service platforms including financial service platforms and distribution platforms. The company has developed the Eternal Information System, which integrates logistics warehousing management, order management, data analysis, procurement/distribution management and time tracking to provide complete solutions for different customer business types and needs. The management team's extensive experience in supply chain management enables EA to maintain and strategically develop its business and work closely with its customers. It can be said that service facilities and network, human capital and technology patents are the basis for competitiveness, and it is also an important factor affecting customers' demand management capabilities, customer relationship management capabilities and supply chain coordination.

2) In terms of supplier integration, the company has established a system for suppliers to choose, according to industry reputation, enterprise scale and other factors. The company cooperates with excellent suppliers, and through the supplier's attention and supplier participation to form a strategic partnership of complementary advantages, realizes the integration of information and technology and resource sharing, and promotes the link between the supply chain outsourcing. When the environment changes, companies can also flexibly change their outsourcing strategies and quickly adapt to the environment through linkage with suppliers. Therefore, supplier integration capability is a direct factor in the formation of EA's competitiveness, and also affects its supply chain flexibility capabilities, customer demand management and other capabilities to promote competitiveness.

3) Eternal Asia company has established a good partnership with domestic and international customers companies, providing supply chain management services for many multinational and domestic enterprises, such as Panasonic, Haier, etc. Due to customers are developing rapidly, so the business stability of Eternal Asia company is guaranteed. Supply chain management services have strong permeability to the customer's supply chain, if some companies are the customers of Eternal Asia company, their customers are easy to become the customers of Eternal Asia company.

4) The company has a dominant position in purchasing channels, suppliers on time delivery rate is $97 \%$, the time of order management is 1 day, customer enterprises' delivery cycle and prompt delivery are effectively guaranteed. When the goods are damaged or short in the course of transportation, the company will immediately contact the buyer's customer and remind them to pay attention to the goods. If the delivery party needs to reissue new products, the company will timely operate to ensure customer's normal production plan.

5) In terms of customer demand management, on the basis of service products, 
EA has penetrated as much as possible into the supply chain of the customer's enterprise, enabling the company to outsource the supply chain business to EA, and the supply chain service scope provided by EA covered the whole production and operation process from product design to raw material supply, production and sales, and plans, organizes, coordinates and controls the logistics, information flow, capital flow and business flow in the supply chain. Good communication enabled EA to quickly adjust and improve the service according to customer feedback, and achieved high customer satisfaction and customer loyalty. EA's service level, information communication and service improvement are important manifestations of its customer's demand management ability. At the same time, it also affects other capabilities such as customer relationship management and supply chain responsiveness in terms of customer loyalty and timeliness of problem handling.

6) In terms of supply chain flexibility, the company integrates the functions of buyers, distributors and logistics service providers, and integrates many industry enterprises into EA resources, with good combination flexibility and delivery flexibility. Through EA's supply chain services, customers can complete supply chain of industries involved in a large number of industries, so that the company has a precise grasp of the industry ecology, can help enterprises to evaluate suppliers, the company's supply chain collaborative management system enables the company to understand the various functional department sations, faster, cheaper and more stable. The consistency and integrity of the information provides data support for the company's analytical market and improves the ability of the decision-making layer to respond to the market.

\section{Acknowledgements}

This paper is supported by Guangdong public welfare research and capacity building special fund project (2015A070704010, 2016A070705021), and the central university basic scientific research operating fund (2015XZD19).

\section{Conflicts of Interest}

The author declares no conflicts of interest regarding the publication of this paper.

\section{References}

[1] Song, H. and Lu, Q. (2017) The Innovation of Supply Chain Finance Pattern Based on Virtual Clusters: A Case Study of SJET. China Industrial Economics, 5, 11-22.

[2] Gao, Z.J. (2015) Synergistic Value Creation Mechanism in High-End Logistics Service-A Case Study of EA. Contemporary Economic Management, 4, 5-7.

[3] Wang, Z.X. (2012) Shenzhen Supply Chain Management Industry Development Report. Economic Management Publishing House.

[4] Grönroos, C. and Ravald, A. (2011) Service as Business Logic: Implications for Value Creation and Marketing. Journal of Service Management, 22, 5-22. https://doi.org/10.1108/09564231111106893 
[5] Wernerfelt B. (1984) A Resource-Based View of the Firm. Strategic Management Journal, 5, 171-180. https://doi.org/10.1002/smj.4250050207

[6] Standing, S. and Standing, C. (2015) Service Value Exchange in B2B Electronic Marketplaces. Journal of Business \& Industrial Marketing, 30, 723-732. https://doi.org/10.1108/JBIM-05-2014-0112

[7] Anderson, E. and Weitz, B. (1992) The Use of Pledges to Build and Sustain Commitment in Distribution Channels. Journal of Marketing Research, 29, 18-34. https://doi.org/10.2307/3172490

[8] Fang, E., Palmatier, R.W. and Evans, K.R. (2008) Influence of Customer Participation on Creating and Sharing of New Product Value. Journal of the Academy of Marketing Science, 36, 322-336. https://doi.org/10.1007/s11747-007-0082-9

[9] Maull, R., Geraldi, J. and Johnston, R. (2012) Service Supply Chains: A Customer Perspective. Journal of Supply Chain Management, 48, 72-86. https://doi.org/10.1111/j.1745-493X.2012.03284.x

[10] Handfield, R.B. and Bechtel, C. (2002) The Role of Trust and Relationship Structure in Improving Supply Chain Responsiveness. Industrial Marketing Management, 31, 367-382. https://doi.org/10.1016/S0019-8501(01)00169-9

[11] Kyj, L.S. and Kyj, M.J. (2013) Customer Service: Product Differentiation in International Markets. International Journal of Physical Distribution \& Logistics Management, 19, 30-38. https://doi.org/10.1108/EUM0000000000305

[12] Zeithaml, V.A., Parasuraman, A. and Berry, L.L. (1985) Problems and Strategies in Services Marketing. Journal of Marketing, 49, 33-46. https://doi.org/10.1177/002224298504900203

[13] Muther, A. and Österle, H. (1998) Electronic Customer Care-Neue Wege zum Kunden. Wirtschaftsinformatik, 40, 105-113.

[14] Tsai, W.H., Yang, C.C., Leu, J.D., et al. (2013) An Integrated Group Decision Making Support Model for Corporate Financing Decisions. Group Decision \& Negotiation, 22, 1103-1127. https://doi.org/10.1007/s10726-012-9308-4

[15] Hu, H.Y., Chiu, S., Yen, T.M., et al. (2015) Assessment of Supplier Quality Performance of Computer Manufacturing Industry by Using ANP and DEMATEL. TQM Journal, 27, 122-134. https://doi.org/10.1108/TQM-11-2012-0091 